Portland State University

PDXScholar

Civil and Environmental Engineering Faculty

Publications and Presentations

Civil and Environmental Engineering

$6-1-2020$

\title{
User-Rated Comfort and Preference of Separated Bike Lane Intersection Designs
}

Christopher Monsere

Portland State University, monsere@pdx.edu

Nathan McNeil

Portland State University, nmcneil@pdx.edu

Rebecca Sanders

Arizona State University at the Tempe Campus

Follow this and additional works at: https://pdxscholar.library.pdx.edu/cengin_fac

Part of the Transportation Engineering Commons

Let us know how access to this document benefits you.

Citation Details

Monsere, C. M., McNeil, N. W., \& Sanders, R. L. (2020). User-Rated Comfort and Preference of Separated Bike Lane Intersection Designs. Transportation Research Record, 0361198120927694.

This Post-Print is brought to you for free and open access. It has been accepted for inclusion in Civil and Environmental Engineering Faculty Publications and Presentations by an authorized administrator of PDXScholar. Please contact us if we can make this document more accessible: pdxscholar@pdx.edu. 
TRR Paper 20-04222: User-Rated Comfort and Preference of Separated Bike Lane Intersection Designs

Christopher M. Monsere (corresponding author)

Professor and Chair

Department of Civil \& Environmental Engineering

Portland State University

Portland, OR 97201

Email: monsere@pdx.edu

ORCID: 0000-0002-9044-307X

Nathan W. McNeil

Research Associate

Center for Urban Studies

Portland State University

Portland, OR 97207-0751

Email: nmcneil@pdx.edu

ORCID: 0000-0002-0490-9794

Rebecca L. Sanders

Assistant Research Professor

Arizona State University

School of Geography and Urban Planning

Tempe, AZ 85281

Email: rlsanders@asu.edu

ORCID: 0000-0002-9259-471X

Submitted August 1, 2019

Revised March 24, 2020

Final Publication April 29, 2020 


\section{ABSTRACT}

2 Improved bicycle infrastructure has become increasingly common in the United States as 3 cities seek to attract the new riders, including the demographics of people who do not feel 4 comfortable riding with motor vehicle traffic. A key tool in low-stress networks are separated or 5 protected bicycle lanes and intersections are the critical links. This paper presents an analysis of 6 the perceived level of comfort of current and potential bicyclists from 277 survey respondents 7 who rated 26 first-person video clips of a bicyclist riding through mixing zones, lateral shifts, 8 bend-in, bend-out and protected intersection designs. A total of 7,166 ratings were obtained from 9 surveys conducted at four locations in Oregon, Minnesota, and Maryland, including urban and 10 suburban locations. Survey respondents were categorized into four groups based on their 11 response to attitudes and bicycling behavior by cluster analysis. Descriptive analysis and 12 regression modeling results find that designs that minimize interactions with motor vehicles, 13 such as fully separated signal phases and protected intersections, are rated as most comfortable 14 (72\% of respondents rated them as very comfortable or somewhat comfortable). Mean comfort 15 drops off significantly for other designs and interactions with turning vehicles result in lower 16 comfort ratings though there are differences for each design. Importantly, as the exposure 17 distance, measured as the distance a person on a bicycle is exposed to traffic, increases the 18 comfort decreases.

19 Keywords: Bicycle facilities, Roadway design, Bicyclist design preferences, Bicyclist comfort 20 


\section{INTRODUCTION}

As cities strive to make streets safe and comfortable for bicycling, facilities that provide separation from motor vehicle traffic on the roadway have become increasingly common. As of 2019, there were 519 documented separated bike lanes totaling 393 lane-miles around the United States according to the Green Lanes Project's Protected Bike Lanes Inventory, up from less than 1 mile in 2007 (1). Generally, separated bike lanes assign bicyclists and motorists their own space on the roadway. At intersections, design options for separated bike lane intersections can be in one of three categories: 1) designs that maintain separation between bicycles and motor vehicles up to the intersection (e.g., straight or maintain separation, bend-in, bend-out, and protected intersection), 2) designs where bicyclists mix with or cross the path of turning motor vehicles (e.g., mixing zones and lateral shift), and 3) designs that use bicycle signals to fully separate the conflicting movements between bicycles and motor vehicles in time (2). The selection of the design is often challenged by space constraints and the need to accommodate turning vehicles. Safety (in terms of reported crashes and observed conflicts) is an essential consideration in the selection of a design. However, the perceived comfort of various intersection designs is also a key consideration for cities attempting to build connected comfortable networks, given the link between comfort facilities and ridership (3-5).

This paper presents research that adds to the relatively scarce data around the perceived comfort of current and potential bicyclists at intersections for newer designs on separated bikeways. The data used in this study were obtained from an in-person rating of curated video clips, shown from the perspective of a bicyclist, riding through the various intersection designs with consistent levels of interactions with turning motor vehicles. A total of 277 survey respondents rated each clip on a comfort scale providing 7,166 ratings. Respondents also answered questions about whether they would ride specific designs with a 10-year old child, indicated a preference for paired sets of intersection designs, and answered questions about their travel experiences and demographics.

\section{BACKGROUND}

Studies have consistently found that people prefer bike facilities that are separated from traffic, such as off-street paths and separated bike lanes (6-9), with physical separation such as a post or curb providing increased comfort (8-11). In most research, the preference for these separated facilities appears to be greater amongst non-transportation cyclists and those who cycle less often (11) and among the subset of potential bicyclists who are classified as interested in cycling for transportation but concerned about safety and other issues $(9,10)$. Clark et al. (12) however, found that (in their set of 6 communities in Tennessee and Alabama), utilitarian cyclists were more responsive than recreational-only or potential cyclists to the presence of bicycle-infrastructure, including separated bike lanes. Overall, the results suggest that providing comfortable designs may be vital to expanding the bicycling population beyond current riders. However, these studies of bicyclists' sense of safety and comfort have generally focused on segments, rather than intersection locations.

Recent studies of the safety of separated bike lanes have tended to be positive overall. A study examining 13 years of crash data across 12 U.S. cities found that higher concentrations of separated bike facilities were strongly associated with better safety outcomes (13). Another review of crash data noted overall trends toward decreases in bicyclist crashes along separated bike lanes (14). Studies in Toronto and Vancouver, Canada used data from interviews with 
nearly 700 injured cyclists identified through hospital records to investigate the likelihood of injury along with various street types. In both studies, even though the number of separated facilities in each city was relatively small, they were found to be significantly less likely to be associated with a crash than all other facility types $(15,16)$. Another study of cycle tracks in Montreal and New York found an overall crash rate of 2.3 crashes per bicycle $\mathrm{km} /$ year lower than reference rates calculated for on-street cycling in multiple studies $(17,18)$.

The effect of separated bike lanes on bicyclist safety at intersections is somewhat unclear. The Rothenberg et al. review of crash data found an increased number of bicycle crashes at intersections along separated bike lanes (14). However, a study examining cyclist and motorvehicle interactions at intersections along separated bike lane routes and control locations found the separated bike lane intersections to be safer, in general, with higher through bicycle traffic being associated with increased safety and higher right-turn motor vehicle traffic being associated with decreased safety (19). Most recently, a study in New York City found a 27\% reduction in crash rates for mixing zones and fully split phasing intersections implemented on separated bikeways (20).

A person's perceived comfort, safety or stress level when using bicycling infrastructure has been quantified by bio-physiological parameters or surveys questions after viewing hypothetical or imagined environments, simulated environments, or through naturalistic studies (e.g. 5, 21-24). Surveys with video clips are one of the most common approaches to assess how people would feel about riding a bicycle in a place that they have never experienced. Petritsch et al. (25) employed this approach to collect 1,709 ratings from 80 participants of 22 different sidepath segments, developing a sidepath LOS model based on average adjacent motor vehicle speed and sidepath lateral separation. Foster et al. (26) extended this general approach to separated bike lane segments, collecting 4,408 ratings across 20 clips and 221 respondents, developing a separated bike lane LOS based on buffer type, one or two-way facility, and average daily motor vehicle volume. In one of the few other studies to consider a level of service type metric for separated bike lane intersections, a Danish study presented respondents with clips of pedestrian and bicycle intersection crossings, including 3,998 satisfaction ratings of 74 intersections, 36 of which were signalized intersections (27). The study found that factors associated with increased bicyclist satisfaction at intersections included having a separated bike lane leading up to the intersection, wider bicycle facilities, and having a painted lane through the intersection. Wang and Akar (28) used still photos in an online survey to assess perceived safety of regular cyclists, potential cyclists and non-cyclists. Although not specifically about separated bike lanes, the study did find that the presence of a cycle track leading up to an intersection increased perceived safety for most users (including regular and potential cyclists), and found that complex intersections and increased traffic were negatively associated with perceived safety for regular and potential cyclists. The study also found other infrastructure such as bicycle boxes, two-stage left turns, and intersection pavement markings were also positively associated with safety for regular and potential cyclists

Findings on the accuracy of assumed comfort when riding on hypothetical facilities are mixed. Fitch and Handy (29) compared stated comfort of cyclists on route they had actually ridden to other respondents stated comfort when imagining they were riding on the same facilities, and found that the actual cyclists stated comfort was higher. However, McNeil et al (9) found presumed comfort on various hypothetical protected bike lanes to be higher that the stated comfort of intercepted bicyclists on facilities with comparable types of separation. 


\section{METHODS}

The research team conducted an extensive inventory to identify candidate intersections on separated bike lanes. After reviewing the options and aiming to minimize dramatic differences between locations, the team selected 10 locations between the cities of Denver, CO, Portland, OR, Salt Lake City, UT, and Seattle, WA. To collect the first-person video data, members of the research team wore helmet-mounted high-definition cameras and rode through a variety of intersection designs in the summer and fall of 2017. The team sought to capture three types of perspectives for each intersection: 1) no turning vehicles present, 2) turning vehicles visible in the forward view but without any impact on the person riding the bicycle, and 3) interactions with the turning motor vehicle at the intersection such as slowing, negotiating space, or yielding. All interactions were naturalistic except in a few cases where low turning volumes required a member of the research team to drive the turning vehicle. Control clips of a bike lane, a separated bike lane, and an off-street trail were also filmed to benchmark to prior studies.

Following data collection, the research team narrowed over 500 videos to a final set of 26 clips to be shown in the survey. Videos were carefully selected so that the clips for each category were as comparable as possible across intersection designs and the number of unique aspects that might influence ratings (e.g., the presence of large vehicles, head-turning of the cyclist, or encroaching pedestrians) was minimized. Table 1 presents the final selection of intersections, including design details such as the dimension of the bend-in or bend-out of the bike lane, the crossing distance (measured as the distance between nearside and farside crosswalks), the length of the mixing or merge zone, and the exposure distance measured upstream from the crossing where the physical protection of the separated bike lane ended to the return to protection (e.g., length of any mixing or crossing zone or sections that revert to non-separated bike lanes).

Each clip was edited to be approximately 10 seconds. Some adjustments in playback speed were made to align the speeds of the bicycle rider in each clip. For the clip with the bicycle traffic signal (Arapahoe and $18^{\text {th }}$ ), the research team annotated the clip to show the presence of a bicycle signal by noting the signal with an arrow and providing a zoomed-in view of the signal face since it was difficult to see in the video clip. During pilot testing of the survey, it became clear that showing three views per intersection produced an unreasonably long survey; thus, clips without any turning vehicles visible were removed from the final survey. The final set of clips included one presentation for each of the three control segments and the bicycle signal intersection. The intersection designs were shown at least twice - once with a turning motor vehicle visible and once with an interaction with a turning motor vehicle. At four locations, an additional interaction clip was shown. Figure 1 shows the images of the 10 intersection locations (the three segment control locations are not shown due to space limitations).

Surveys were conducted in person in a room set up with a video projector and sound system to more accurately reflect traffic noise and conditions. Locations were selected for high volumes of foot traffic. Locations included a farmer's market in Portland, Oregon, a community center in Takoma Park, Maryland, and shopping centers in Minneapolis, Minnesota, and Woodburn, Oregon. Surveys were conducted on weekend days between May and July 2018. Participants were recruited by asking if they would be interested in taking a transportation survey with the opportunity to receive a \$5 gift card. The first section of the survey involved watching the video clips then marking how comfortable they would feel if they were riding a bicycle in that place. The rating scale of 1 for "Very Uncomfortable," 2 for "Somewhat Uncomfortable," 3 for "Neither Uncomfortable nor Comfortable"; 4 for "Somewhat Comfortable", and 5 for "Very 
Comfortable" was used. The video clips played on a continuous loop, and respondents could start at any point in the loop. Each of the 10-second clips were shown two times, after which the respondent was presented with a screen asking them to rate the clip. Several clips were shown a third time, and respondents were asked if they would ride (yes or no) in that location with a tenyear-old child.

After completing the video portion of the survey, respondents were given a paper exit survey. The survey asked respondents to compare two pairs of intersections, first marking which of the first pair they preferred, then the second pair, and finally, the overall preference. For each selection, they were asked to specify why they preferred that intersection. The first pairing was two designs that mixed bicycle and turning motorist paths, a mixing zone from NE Multnomah St. in Portland and a lateral shift design from Roosevelt Way NE in Seattle. The second pairing was two designs that maintained separation: a protected intersection on 300S in Salt Lake City and a bend-in design on West $14^{\text {th }}$ Ave. in Denver (see images in Figure 1). Finally, respondents were asked about bicycling behavior, attitudes general demographics. A total of 277 survey responses were collected and coded, providing 7,166 clip ratings.

\section{RESULTS}

This section first presents the basic demographics of the survey respondents, then explores the comfort ratings and design preferences and the riding with children questions. A cluster analysis was conducted based on attitudes and perceptions toward bicycling to identify potential groups that may want to bicycle more but are more sensitive to comfort (or lack thereof) to identify patterns in comfort scores by cyclist typology.

\section{Demographics}

Respondent characteristics are shown in Table 2. The 275 respondents were distributed equally between the age groups of 18 to 24,25 to 34,35 to 54 , and 55 and over, and just over half of all respondents (56\%) were women. Across all sites, respondents were $65 \%$ non-Hispanic white, 9\% Hispanic or Latino, 11\% Asian, 5\% Black or African American, and 1\% American Indian or Alaska native. Just about two-thirds of respondents work full-time, ranging from a low of $49 \%$ in Portland to a high of $77 \%$ in Minneapolis. Eighteen percent of respondents were also full-time students, along with $5 \%$ who are part-time students. Nine out of ten respondents had a driver's license, while $58 \%$ had a working bicycle, $45 \%$ had a transit pass, and $57 \%$ had a car or truck. In terms of bicycling experience, just over three-quarters of respondents told us that had ridden in the past year on a trail, path, or quiet residential street. Only about half (53\%) had ridden on a bike lane on a busy street, and $41 \%$ had ridden on a busy road without a bike lane, with the same percentage having ridden in a protected bike lane on such a street. The overall demographics of the survey represented a reasonable sample of the population though was younger than the average for each location (except for Takoma Park), a more likely to be female, and a more likely to be white compared to ACS city-level data (not shown in Table).

\section{Comfort ratings by intersection design}

Table 3 shows the mean comfort rating (see Figure 2 as well) along with the percentage of respondents who rated clips as either very comfortable or somewhat comfortable (Figure 3). The ratings are categorized by the intersection designs. For the control segments, the overall mean ratings are in the expected order and compare well to Foster et al. (26), who used a similar methodology. Off-street trails received the highest score (4.77) followed by the protected bicycle 
1 lane (4.54). The standard bike lane received the lowest mean rating of all clips (2.79). For the 2 intersection designs, the signalized (3.77) and protected intersections (3.78) received the highest 3 overall mean comfort scores and were rated as comfortable by two-thirds of respondents. The bend-in (3.30) and maintain separation design (3.22) were rated as comfortable by just under half of the respondents. Mixing zones (3.04) and lateral shift designs (2.97) were rated the least comfortable options as comfortable by just over a third of respondents.

In situations where the bicyclists and turning motor vehicles interacted (defined as arriving at the intersection at a same time, necessitating an interaction such as one or the other slowing, yielding, merging, or crossing), the percentage of respondents who would be comfortable dropped for most designs. The most significant drop was for the maintain separation (24\%) and bend-in (14\%) designs. The protected intersection only design changed by $9 \%$ with $63 \%$ reporting they would still be comfortable even in the presence of turning vehicles. Interestingly, the mixing zone locations saw no difference in the percentage of respondents indicating they would be comfortable.

\section{Design preference comparison}

Following the video survey, respondents were asked to choose which of four intersection designs they would prefer and to explain their choice briefly. Options were presented in pairs initially, and open-ended responses of the stated preference were coded for each pair choice. Overall, the 259 respondents indicated that they preferred more defined separation from motor vehicles. For the first pairing, most chose the lateral shift (61\%) over the mixing zone (39\%). Stated reasons for each preference included:

- Mixing zone: preferred the yield sign/markings (19\% of those who selected this choice), like not having to cross a car lane (18\%), and like being able to stay to the right (10\%).

- Lateral shift: liked the separation from vehicles (35\% of those who selected this choice) and the clear lane marking (31\%), and that they like the green color (21\%) of the pavement.

In the second pair, respondents chose the protected intersection (83\%) overwhelmingly over the bend-in design (17\%). Stated reasons included:

- Protected intersection: liked the protection and separation from vehicles (43\% of those who selected this choice), felt the design provided improved visibility and/or a safer turning angle (34\%), that it had clear markings (17\%), and that the design slows down drivers, and provides more time to react (13\%).

- Bend-in: felt the design was less confusing (34\% of those who selected this choice), and that it provided better visibility and made drivers more alert to the potential for bicyclists (16\%).

Finally, respondents were asked to rate which of the four designs they preferred. Among all four choices, 73\% preferred the protected intersection, followed by the bend-in (11\%), lateral shift

39 (10\%), and mixing zone (6\%). Table 4 presents the overall preference for a design and reasons

40 for this selection. 


\section{Comfort ratings by typology of cyclist}

Additional analysis was conducted to learn if there were differences in stated comfort based on how people viewed bicycling in general, if they might be interested in riding and the types of concerns they had about riding. The respondent data obtained in the brief survey did not allow each respondent to be fit into a cyclist typology along the lines of that proposed by Geller (30) and tested by Dill and McNeil $(10,31)$. Instead, K-Means Clustering, a cluster analysis approach that organically identifies a predefined number of groups based on how similar they are to other members of the group was used (32). The clustering was based on a set of bike-related attitude and perception variables included in the survey.

Table 5 includes the attitude and perception variables that were the basis for the clustering, while the subsequent sections of the table provide descriptive information on the travel behavior, demographics, and location characteristics of the people in each cluster. Three distinct groups were identified:

- Group one respondents $(\mathrm{n}=72)$ are a little less interested in bicycling, much less likely to view destinations as bikeable and see people like themselves riding in their neighborhood. They were also the least likely to have ridden a bike for transportation, or to have a transit pass, and were most likely to take most trips by car. Based on home zip codes provided by respondents, they also lived in areas with lower population density. These are labeled as "Indifferent to Bicycling."

- Group two respondents (n=93) were least likely to say that traffic keeps them from riding a bicycle. Nearly all group two respondents felt that destinations were within bikeable distances and that they saw people like them riding in their neighborhoods. They were most likely to have biked for transport and were more likely than respondents in other groups to be male and white. These are "Bike Inclined."

- Group three respondents ( $\mathrm{n}=93)$ were nearly all interested in biking more but felt that traffic kept them from riding more. They were also more likely than other respondents to be female. Due to their similarity to the group identified in Gellar's Types of Cyclist typology, these respondents were labeled as "Interested but Concerned."

Table 6 shows the mean rating of each intersection type for each cluster group, along with the percentage of respondents who indicated that they would feel either somewhat or very comfortable riding through that intersection. Across most of the surveyed intersection types, the Bike Inclined were the most likely to rate each as being comfortable to ride through. The Indifferent to Bicycling and Interested but Concerned groups were consistent across many intersection types, with a few exceptions. Interested but Concerned respondents were less comfortable riding through the maintain separation location (just 34\% of Interested but Concerned respondents would be comfortable at this location, in comparison to $46 \%$ of the Indifferent to Bicycling group). There were no significant differences between the groups in terms of comfort for the bike signal location. Overall, the mean rating and percentage of respondents indicating comfort were lower for the Interest but Concerned group than for either of the other groups, including the Indifferent to Bicycling group. This group still had strong reported comfort for the protected intersection (64\%) and the signal option (65\%). 


\section{Riding with children}

Respondents were also asked if they would consider riding in the location with a tenyear-old child for six clips. The selected locations included five types of intersections, for which each clip showed a turning car visible, but without direct interaction between the cyclist and car. A sixth clip was a protected bike lane. Figure 4 presents the percentage indicating they would ride in that location with a child. The protected bike lane ranked the highest, with $89 \%$ of respondents indicating they ride there with a child. Next were the bend-in and the protected intersection, with $70 \%$ and $68 \%$ respectively. The maintain straight path and separation location had just about half of the respondents indicating they would ride with a child, while the lateral shift (31\%) and mixing zone (25\%) were lowest.

These responses were tabulated by the factor groups (Table 7). The Interested but Concerned group were more likely than those in the Indifferent to Bicycling group to say they would ride with children in several locations, including through the protected intersection and through the short mixing zone. The Bike Inclined group, as expected, indicated a greater willingness to ride with a ten-year-old child in most of the locations, although in a number of cases, including the separated bike lane segment and the maintain separation / straight path location, the differences were not significant.

\section{Regression analysis of comfort ratings}

A number of ordinal regression models were developed and tested to explore the effect of design-level variables and others on comfort scores while controlling for person-level variation. Exposure distance emerged as the only significant design factor in comfort ratings. Figure 5 shows the average percentage of respondents indicating that they would be either somewhat or very comfortable compared to the distance the rider would be exposure (the loss of physical protection in the separated bike lane to the far side of the intersection). Uncontrolled for other factors, the trend is quite clear - intersection and designs with longer exposed distances for the bicyclist, either through mixing or crossover areas prior to the intersection, or longer crossing distances were generally rated as less comfortable designs.

Independent linear regression models were created for each cluster group to examine how the effect of the exposure distance. The models, summarized in Table 8, included the comfort rating as the dependent variable, and the mix/merge length and crossing distance as the independent variables. While the $\mathrm{R}^{2}$ values are relatively low, the models confirm that the longer the exposure distance, the lower the expected comfort, with an average effect on the comfort ratings of negative 0.011 per foot of combined exposure. As an example, an intersection with 140 feet of exposure compared to 50 feet of exposure would be one rating down one notch on our five-point comfort scale. Further, the results suggest that the mix/merge length exposure (at 0.007 per foot) is near twice the negative impact as the crossing distance (at -0.004).

With respect to the cluster group types, the Bike Inclined start from a higher baseline comfort level (with the constant of 4.021 roughly equating to an average rating of "somewhat comfortable") and lose a combined 0.010 per foot of exposure. Meanwhile, the Interested but Concerned group starts at a lower average rating of 3.536 and loses comfort at a faster rate of 0.012 per foot of exposure. While the model values are not highly predictive, they do suggest that Interested but Concerned group are more sensitive to exposure. 


\section{CONCLUSION}

When considering the expected level of comfort, protected intersections and bike signals were found to provide the best expected rider comfort. Designs that move bicyclists and motor vehicles into shared space (mixing zones or lateral shifts) were viewed as least comfortable. Designs that keep a separate bike lane (bend-in, straight-path) were rated as comfortable by more than half of all respondents but were particularly sensitive to the presence of turning vehicles. It may be that, without the vehicles in the video clip, the design implies separation from vehicles and is rated higher but when shown interacting with vehicles, it is more apparent to the extent cyclists must mix with traffic. There was not a difference in the comfort of mixing zone designs with or without vehicle interactions. One potential reason for this is that mixing zones cyclists and motor vehicles are already primed for interaction (as opposed to separated spaces). Additionally, in most of the cases in which cyclists were negotiating interactions with turning vehicles, the vehicles were moving quite slowly. The overall comfort levels found in our study were lower than a recent comparable study in New York, NY that included forms of protected intersections and mixing zones (20) however we believe the results are consistent when considering that study only intercepted current cyclists and the question was worded as "I feel safe cycling through this intersection. Sundstrom et al. (19) found that $65 \%$ felt safe in the mixing zone and 93\% in the offset design (similar to the protected intersection).

There are a significant number of infrequent cyclists who are interested in riding more,

The survey results about riding with children provide valuable insights but should be but not comfortable with many types of bicycle facilities. These individuals fall into Interested but Concerned group of the K-means cluster analysis. They are less comfortable than the Bike Inclined (who may be comparable to the Enthused and Confident or Strong and Fearless cyclists in the four types typology) across a variety of facilities. In particular, facilities with any form of mixing before the intersection (e.g., mixing zones, lateral shift) are likely to drop the Interested but Concerned group down below the point where even $30 \%$ would feel comfortable riding through the facility. The locations with bike signal and protected intersection resulted in about two-thirds of the Interested but Concerned respondents indicating they would feel comfortable riding there. The facilities with bend-in designs and maintaining separation were generally in between the two other types for the Interested but Concerned group (about 30 to $40 \%$ felt comfortable.

The cluster analysis also revealed a group of individuals who don't view biking as being particularly useful for them - they are more likely to view destinations as not being within bikeable distances and preferring other modes to bicycles. There is some indication that they exhibited less sensitivity to the different designs and interactions than other respondents. For example, they didn't rate clips with interactions with turning vehicles lower than those without such interactions (while the other two groups did), and they have a narrower band of comfort ratings than those in group 3 (i.e., their ratings ranged from $24 \%$ for the lowest-rated individual location to $90 \%$ for the highest, while the Interested but Concerned group ranged from $18 \%$ to 95\%). The Interested but Concerned group, on the other hand, may be more sensitive to intersection design than the average non-cyclist. This corroborates past research finding that they tend to be the most responsive to changes in the design environments in stated preferences (9, 11) . interpreted with caution as they are each based on a single video clip, without any interaction 
with a turning vehicle. The bend-in design and protected intersection were the highest-rated intersection locations, while the lateral shift and mixing zone locations were the lowest.

Finally, exposure distance was found to be a significant predictor of comfort. Interested

but Concerned respondents were particularly sensitive to the exposure distance, with the upstream exposure lowering comfort more than that the crossing distance exposure. From a comfort viewpoint, shortening exposure distance is a good design objective.

There are a few important limitations to this research. First, the sample was not a random

\section{ACKNOWLEDGMENTS} sample and although we attempted to include a diversity of respondents, self-selection likely played a role in who responded. The mostly naturalistic video collection approach both limited the video that could be presented, while also introducing some potential compounding factors such as adjacent vehicles and noise. We have also relied on the presumed but not confirmed connection between ratings and if people would actually ride. Future research should seek to establish the actual safety of these intersection designs.

This project was funded by a pooled fund organized by the National Institute for Transportation and Communities (NITC) grant number NITC-RR-987. Pooled fund contributors include the Portland Bureau of Transportation, the City of Cambridge, Massachusetts, SRAM Cycling Fund, and TriMet. Toole Design Group (Rob Burchfield and Bill Schultheiss) contributed to this research.

\section{AUTHOR CONTRIBUTIONS}

The authors Monsere (CM), McNeil (NM) and Sanders (RS) confirm contribution to the paper as follows: study conception and design: CM, NM, RS; data collection: CM and NM; analysis and interpretation of results: NM, CM, RS; draft manuscript preparation: CM, NM, RS. All authors reviewed and approved the final version of the manuscript.

\section{REFERENCES}

1. PeopleForBikes. Protected Bike Lanes Inventory. https://peopleforbikes.org/green-laneproject/inventory-protected-bike-lanes/.

2. Federal Highway Administration. Separated Bike Lane Planning and Design Guide. Publication FHWA-HEP-15-025. 2015, p. 148p.

3. Dill, J., and T. Carr. Bicycle Commuting and Facilities in Major U.S. Cities: If You Build Them, Commuters Will Use Them. Transportation Research Record, Vol. 1828, No. 1, 2003, pp. 116-123. https://doi.org/10.3141/1828-14.

4. Broach, J., J. Dill, and J. Gliebe. Where Do Cyclists Ride? A Route Choice Model Developed with Revealed Preference GPS Data. Transportation Research Part A: Policy and Practice, Vol. 46, No. 10, 2012, pp. 1730-1740. https://doi.org/10.1016/j.tra.2012.07.005.

5. Blanc, B., and M. Figliozzi. Modeling the Impacts of Facility Type, Trip Characteristics, and Trip Stressors on Cyclists' Comfort Levels Utilizing Crowdsourced Data: Transportation Research Record, 2016. https://doi.org/10.3141/2587-12.

6. Tilahun, N. Y., D. M. Levinson, and K. J. Krizek. Trails, Lanes, or Traffic: Valuing Bicycle Facilities with an Adaptive Stated Preference Survey. Transportation Research Part A: Policy and Practice, Vol. 41, No. 4, 2007, pp. 287-301. https://doi.org/10.1016/j.tra.2006.09.007. 
7. Winters, M., G. Davidson, D. Kao, and K. Teschke. Motivators and Deterrents of Bicycling: Comparing Influences on Decisions to Ride. Transportation, Vol. 38, No. 1, 2011, pp. 153168. https://doi.org/10.1007/s11116-010-9284-y.

8. Sanders, R. L. We Can All Get along: The Alignment of Driver and Bicyclist Roadway Design Preferences in the San Francisco Bay Area. Transportation Research Part A: Policy and Practice, Vol. 91, 2016, pp. 120-133. https://doi.org/10.1016/j.tra.2016.06.002.

9. McNeil, N., C. M. Monsere, and J. Dill. Influence of Bike Lane Buffer Types on Perceived Comfort and Safety of Bicyclists and Potential Bicyclists. Transportation Research Record, Vol. 2520, No. 1, 2015, pp. 132-142. https://doi.org/10.3141/2520-15.

10. Dill, J., and N. McNeil. Revisiting the Four Types of Cyclists: Findings from a National Survey. Transportation Research Record: Journal of the Transportation Research Board, No. 2587, 2016, p. pp 90-99.

11. Sanders, R. L., and B. Judelman. Perceived Safety and Separated Bike Lanes in the Midwest: Results from a Roadway Design Survey in Michigan. Transportation Research Record, Vol. 2672, No. 36, 2018, pp. 1-11. https://doi.org/10.1177/0361198118758395.

12. Clark, C., P. Mokhtarian, G. Circella, and K. Watkins. User Preferences for Bicycle Infrastructure in Communities with Emerging Cycling Cultures. Transportation Research Record, Vol. 2673, No. 12, 2019, pp. 89-102. https://doi.org/10.1177/0361198119854084.

13. Marshall, W. E., and N. N. Ferenchak. Why Cities with High Bicycling Rates Are Safer for All Road Users. Journal of Transport \& Health, Vol. 13, 2019. https://doi.org/10.1016/j.jth.2019.03.004.

14. Rothenberg, H., D. Goodman, and C. Sundstrom. Separated Bike Lane Crash Analysis. Presented at the Transportation Research Board 95th Annual MeetingTransportation Research Board, 2016.

15. Harris, M. A., C. C. O. Reynolds, M. Winters, P. A. Cripton, H. Shen, M. L. Chipman, M. D. Cusimano, S. Babul, J. R. Brubacher, S. M. Friedman, G. Hunte, M. Monro, L. Vernich, and K. Teschke. Comparing the Effects of Infrastructure on Bicycling Injury at Intersections and Non-Intersections Using a Case-Crossover Design. Injury Prevention, Vol. 19, No. 5, 2013, pp. 303-310. https://doi.org/10.1136/injuryprev-2012-040561.

16. Teschke, K., M. A. Harris, C. C. Reynolds, M. Winters, S. Babul, M. Chipman, M. D. Cusimano, J. R. Brubacher, G. Hunte, S. M. Friedman, M. Monro, H. Shen, L. Vernich, and P. A. Cripton. Route Infrastructure and the Risk of Injuries to Bicyclists: A Case-Crossover Study. American journal of public health, Vol. 102, No. 12, 2012, pp. 2336-2343. https://doi.org/10.2105/AJPH.2012.300762.

17. Lusk, A., P. Morency, L. Miranda-Moreno, W. Willett, and J. Dennerlein. Bicycle Guidelines and Crash Rates on Cycle Tracks in the United States. American Journal of Public Health, Vol. 103, No. 7, 2013, pp. 1240-1248. https://doi.org/10.2105/AJPH.2012.301043.

18. Lusk, A. C., P. G. Furth, P. Morency, L. F. Miranda-Moreno, W. C. Willett, and J. T. Dennerlein. Risk of Injury for Bicycling on Cycle Tracks versus in the Street. Injury Prevention, Vol. 17, No. 2, 2011, pp. 131-135. https://doi.org/10.1136/ip.2010.028696.

19. Zangenehpour, S., J. Strauss, L. F. Miranda-Moreno, and N. Saunier. Are Signalized Intersections with Cycle Tracks Safer? A Case-Control Study Based on Automated Surrogate Safety Analysis Using Video Data. Accident Analysis \& Prevention, Vol. 86, 2016, pp. 161-172. https://doi.org/10.1016/j.aap.2015.10.025. 
20. Sundstrom, C., S. Quinn, T. Wright, A. Friedman, P. Kennedy, N. Carey, and Z. Wyche. Cycling at a Crossroads: The Design Future of New York City Intersection. New York City Department of Transportation, 2018.

21. Abadi, M. G., and D. S. Hurwitz. Bicyclist's Perceived Level of Comfort in Dense Urban Environments: How Do Ambient Traffic, Engineering Treatments, and Bicyclist Characteristics Relate? Sustainable Cities and Society, Vol. 40, 2018, pp. 101-109. https://doi.org/10.1016/j.scs.2018.04.003.

22. Abadi, M. G., D. S. Hurwitz, and K. L. Macuga. Towards Safer Bicyclist Responses to the Presence of a Truck near an Urban Loading Zone: Analysis of Bicyclist Perceived Level of Comfort. Journal of Safety Research, Vol. 71, 2019, pp. 181-190. https://doi.org/10.1016/j.jsr.2019.09.023.

23. Berger, M., and L. Dörrzapf. Sensing Comfort in Bicycling in Addition to Travel Data. Transportation Research Procedia, Vol. 32, 2018, pp. 524-534. https://doi.org/10.1016/j.trpro.2018.10.034.

24. Caviedes, A., and M. Figliozzi. Modeling the Impact of Traffic Conditions and Bicycle Facilities on Cyclists' on-Road Stress Levels. Transportation Research Part F: Traffic Psychology and Behaviour, Vol. 58, 2018, pp. 488-499. https://doi.org/10.1016/j.trf.2018.06.032.

25. Petritsch, T. A., S. Ozkul, P. McLeod, B. Landis, and D. McLeod. Quantifying Bicyclists' Perceptions of Shared-Use Paths Adjacent to the Roadway. Transportation Research Record, Vol. 2198, No. 1, 2010, pp. 124-132. https://doi.org/10.3141/2198-14.

26. Foster, N., C. M. Monsere, J. Dill, and K. Clifton. Level-of-Service Model for Protected Bike Lanes. Transportation Research Record, Vol. 2520, No. 1, 2015, pp. 90-99. https://doi.org/10.3141/2520-11.

27. Jensen, S. U. Pedestrian and Bicycle Level of Service at Intersections, Roundabouts, and Other Crossings. Presented at the Transportation Research Board 92nd Annual MeetingTransportation Research Board, 2013.

28. Wang, K., and G. Akar. The Perceptions of Bicycling Intersection Safety by Four Types of Bicyclists. Transportation Research Part F: Traffic Psychology and Behaviour, Vol. 59, 2018, pp. 67-80. https://doi.org/10.1016/j.trf.2018.08.014.

29. Fitch, D. T., and S. L. Handy. The Relationship between Experienced and Imagined Bicycling Comfort and Safety. Transportation Research Record, Vol. 2672, No. 36, 2018, pp. 116-124. https://doi.org/10.1177/0361198118787635.

30. Geller, R. Four Types of Cyclists. 2006.

31. Dill, J., and N. McNeil. Four Types of Cyclists? Examination of Typology for Better Understanding of Bicycling Behavior and Potential. Transportation Research Record: Journal of the Transportation Research Board, Vol. 2387, 2013, pp. 129-138. https://doi.org/10.3141/2387-15.

32. Trevino, A. Introduction to K-Means Clustering. Datascience.com. https://www.datascience.com/blog/k-means-clustering. Accessed Jul. 25, 2019. 
Monsere, McNeil, and Sanders

\section{LIST of FIGURES}

2

3 Figure 1 Still video images of intersections used in survey video

4 Figure 2 Mean comfort score, with and without turning interactions

5 Figure 3 Mean comfort score and percentage comfortable, intersection designs

6 Figure 4 Percentage that would consider riding with a ten-year-old child, by intersection design

7 Figure 5 Percent of respondents rating intersection as "comfortable" by exposure distance 8 
Monsere, McNeil, and Sanders

1 Table 1 Summary of Intersection Design Details

\begin{tabular}{|c|c|c|c|c|c|c|c|}
\hline Location & City & $\begin{array}{l}\text { Design } \\
\text { Type }\end{array}$ & $\begin{array}{c}\text { Bend } \\
\text { (ft.) }\end{array}$ & $\begin{array}{l}\text { Mix/merge } \\
\text { length (ft.) }\end{array}$ & $\begin{array}{l}\text { Crossing } \\
\text { distance } \\
\text { (ft.) }\end{array}$ & $\begin{array}{l}\text { Exposure } \\
\text { distance }^{1} \\
\text { (ft.) }\end{array}$ & $\begin{array}{r}\text { Number of } \\
\text { Lanes on } \\
\text { Approach }\end{array}$ \\
\hline $\begin{array}{l}\text { NE Multnomah at } \\
11^{\text {th }} E B\end{array}$ & Portland, OR & $\begin{array}{l}\text { Maintain } \\
\text { separation }\end{array}$ & - & - & 42 & 54 & 3 \\
\hline $\begin{array}{l}\text { NE Multnomah at } 9^{\text {th }} \\
\text { WB }\end{array}$ & Portland, OR & $\begin{array}{l}\text { Mixing } \\
\text { zone }\end{array}$ & - & 95 & 50 & 162 & 4 \\
\hline $200 \mathrm{~W}$ at $300 \mathrm{~S} \mathrm{NB}$ & $\begin{array}{l}\text { Salt Lake City, } \\
\text { UT }\end{array}$ & $\begin{array}{l}\text { Protected } \\
\text { intersectio } \\
\mathrm{n}\end{array}$ & 12 & - & $15+25^{2}$ & $15+25^{2}$ & 3 \\
\hline $300 \mathrm{~S}$ at $200 \mathrm{E} \mathrm{EB}$ & $\begin{array}{l}\text { Salt Lake City, } \\
\text { UT }\end{array}$ & $\begin{array}{l}\text { Mixing } \\
\text { zone }\end{array}$ & - & 30 & 99 & 145 & 4 \\
\hline Lawrence at $19^{\text {th }}$ & Denver, CO & $\begin{array}{l}\text { Lateral } \\
\text { shift }\end{array}$ & 15 & 110 & 60 & 190 & 4 \\
\hline Roosevelt at $50^{\text {th }} \mathrm{SB}$ & Seattle, WA & $\begin{array}{l}\text { Lateral } \\
\text { shift }\end{array}$ & 10 & 55 & 46 & 140 & 3 \\
\hline $\begin{array}{l}\text { Dexter at Harrison } \\
\text { NB }\end{array}$ & Seattle, WA & $\begin{array}{l}\text { Mixing } \\
\text { zone }\end{array}$ & - & 40 & 50 & 102 & 4 \\
\hline 14th at Delaware EB & Denver, CO & Bend-in & 8 & - & 50 & 65 & 2 \\
\hline $300 \mathrm{~S}$ at $300 \mathrm{E}$ EB & $\begin{array}{l}\text { Salt Lake City, } \\
\text { UT }\end{array}$ & Bend-in & 12 & 45 & 104 & 199 & 3 \\
\hline Arapahoe at 18th WB & Denver, CO & Bike signal & - & - & 60 & 78 & 3 \\
\hline
\end{tabular}

$2{ }^{1}$ loss of buffer/protection to the far side of the street

32 The protected intersection location crossing had a median, thus breaking the crossing distance into two sections of

415 feet and then 25 feet. 
Monsere, McNeil, and Sanders

1 Table 2 Summary of Respondent Characteristics

\begin{tabular}{|c|c|c|c|c|c|c|}
\hline Variable & Category & $\begin{array}{l}\text { Portland, } \\
\text { OR }\end{array}$ & $\begin{array}{c}\text { Woodburn, } \\
\text { OR } \\
\end{array}$ & $\begin{array}{c}\text { Minneapolis, } \\
\text { MN } \\
\end{array}$ & $\begin{array}{c}\text { Takoma } \\
\text { Park, MD }\end{array}$ & Total \\
\hline \multirow[t]{4}{*}{ Age } & 18 to 24 & $16 \%$ a & $41 \%$ & $39 \%$ & $11 \%$ a & $23 \%$ \\
\hline & 25 to 34 & $33 \%$ ab & $21 \%$ bc & $42 \%$ a & $13 \% \%_{c}$ & $28 \%$ \\
\hline & 35 to 54 & $22 \%$ abc & $33 \% \%_{c}$ & $12 \%$ b & $33 \%$ ac & $25 \%$ \\
\hline & $55+$ & $29 \%$ a & $5 \%$ b & $7 \%$ b & $43 \%$ a & $25 \%$ \\
\hline $\begin{array}{l}\text { Gender } \\
\text { Identity }\end{array}$ & Female & $57 \%$ & $48 \%$ & $54 \%$ & $58 \%$ & $56 \%$ \\
\hline \multirow{6}{*}{$\begin{array}{l}\text { Race and } \\
\text { Ethnicity }\end{array}$} & White, non-Hispanic & $66 \%$ a & $31 \%$ & $81 \% a$ & $72 \%$ a & $65 \%$ \\
\hline & Hispanic or non-white & $28 \%$ a & $60 \%$ b & $16 \%$ a & $17 \%$ a & $27 \%$ \\
\hline & $\begin{array}{l}\text { Hispanic, Latino, or Spanish } \\
\text { origin }\end{array}$ & $7 \%$ a & $26 \%$ & $7 \%$ & $4 \% a$ & $9 \%$ \\
\hline & $\begin{array}{l}\text { American Indian or Alaska } \\
\text { Native }\end{array}$ & $1 \%$ & $2 \%$ & $0 \%$ & $0 \%$ & $1 \%$ \\
\hline & Asian & $13 \%$ ab & $26 \%$ b & $9 \%$ a & $1 \%$ c & $11 \%$ \\
\hline & Black or African American & $5 \%$ ab & $5 \%$ ab & $0 \% \mathrm{~b}$ & $9 \% a$ & $5 \%$ \\
\hline \multirow{4}{*}{$\begin{array}{l}\text { Employment } \\
\text { Status }\end{array}$} & full-time & $49 \%$ a & $76 \%$ & $77 \%$ & $72 \% \mathrm{~b}$ & $65 \%$ \\
\hline & part-time & $25 \%$ a & $12 \%$ ab & $18 \% \%_{a b}$ & $12 \%$ b & $18 \%$ \\
\hline & not employed & $11 \%$ & $10 \%$ & $5 \%$ & $5 \%$ & $8 \%$ \\
\hline & retired & $14 \%$ a & $2 \%$ bc & $0 \% \%_{\mathrm{c}}$ & $11 \%_{\mathrm{ab}}$ & $9 \%$ \\
\hline \multirow{4}{*}{$\begin{array}{l}\text { Travel } \\
\text { Options }\end{array}$} & Have driver's license & $83 \%$ a & $93 \%$ ab & $96 \%$ a & $95 \%$ a & $90 \%$ \\
\hline & Have a working bicycle & $56 \%$ a & $37 \%$ b & $74 \% \%_{c}$ & $60 \%$ ac & $58 \%$ \\
\hline & Have a transit pass & $42 \%$ a & $12 \% \mathrm{~b}$ & $32 \% a$ & $77 \% \%_{c}$ & $45 \%$ \\
\hline & Have a car or truck & $48 \%$ a & $54 \%$ a & $74 \%$ b & $57 \%$ a & $57 \%$ \\
\hline \multirow{6}{*}{$\begin{array}{l}\text { In the past } \\
\text { year, have } \\
\text { you ridden a } \\
\text { bicycle on... } \\
\text { (percent } \\
\text { responding } \\
\text { "yes") }\end{array}$} & $\begin{array}{l}\text { a path or trail separate from } \\
\text { the street }\end{array}$ & $75 \%$ & $71 \%$ & $80 \%$ & $79 \%$ & $76 \%$ \\
\hline & a quiet residential street & $74 \%$ & $71 \%$ & $85 \%$ & $77 \%$ & $77 \%$ \\
\hline & $\begin{array}{l}\text { a busy street w/ speeds up to } \\
30 \mathrm{mph} \text {, WITH a bike lane }\end{array}$ & $59 \%$ & $44 \%$ & $58 \%$ & $45 \%$ & $53 \%$ \\
\hline & $\begin{array}{l}\text { a busy street w/ speeds up to } \\
30 \text { mph, WITHOUT a bike } \\
\text { lane }\end{array}$ & $41 \%$ ab & $27 \%$ & $53 \%$ a & $38 \% a b$ & $41 \%$ \\
\hline & $\begin{array}{l}\text { a busy street with speeds up } \\
\text { to } 30 \text { mph, with a } \\
\text { physically-separated bike } \\
\text { lane (e.g., with a curb, posts } \\
\text { or planter boxes) }\end{array}$ & $54 \%$ a & $23 \%$ & $42 \%{ }_{\mathrm{ac}}$ & $35 \%{ }_{b c}$ & $41 \%$ \\
\hline & n range & $96-99$ & $39-42$ & $56-57$ & $74-77$ & $268-275$ \\
\hline
\end{tabular}

$2 a, b, c$ : Each subscript letter denotes a subset whose column proportions do not differ significantly from each other

3 at the 05 level. (Chi-square with posthoc Z-test) 
1 Table 3 Mean rating and percentage of respondents comfortable, by facility and interaction with

2 turning motor vehicle

\begin{tabular}{|c|c|c|c|c|c|c|c|}
\hline \multirow{2}{*}{$\begin{array}{l}\text { Bicycle } \\
\text { Facility }\end{array}$} & \multicolumn{2}{|c|}{ No interaction } & \multicolumn{2}{|c|}{$\begin{array}{c}\text { Interaction with turning } \\
\text { vehicle }\end{array}$} & \multicolumn{2}{|r|}{ Total } & \multirow{2}{*}{$\begin{array}{c}\text { Number } \\
\text { of } \\
\text { ratings }\end{array}$} \\
\hline & $\begin{array}{l}\text { Mean } \\
\text { Rating }\end{array}$ & $\begin{array}{c}\text { Percentage } \\
\text { comfortable }^{1}\end{array}$ & $\begin{array}{l}\text { Mean } \\
\text { Rating }\end{array}$ & $\begin{array}{c}\text { Percentage } \\
\text { comfortable }^{1}\end{array}$ & $\begin{array}{c}\text { Mean } \\
\text { Ratin } \\
\text { g } \\
\end{array}$ & $\begin{array}{c}\text { Percentage } \\
\text { comfortable }^{1}\end{array}$ & \\
\hline Bike Lane & & & & & 2.79 & $33 \%$ & 276 \\
\hline Trail & \multirow{2}{*}{\multicolumn{4}{|c|}{ Not differentiated }} & 4.77 & $95 \%$ & 276 \\
\hline $\begin{array}{l}\text { Protected Bike } \\
\text { Lane }\end{array}$ & & & & & 4.54 & $91 \%$ & 276 \\
\hline Bicycle Signal & & & & & 3.77 & $67 \%$ & 275 \\
\hline $\begin{array}{l}\text { Protected } \\
\text { Intersection* }\end{array}$ & 3.95 & $72 \%$ & 3.70 & $63 \%$ & 3.78 & $66 \%$ & 828 \\
\hline Bend-in* & 3.47 & $54 \%$ & 3.12 & $40 \%$ & 3.30 & $47 \%$ & 1105 \\
\hline $\begin{array}{l}\text { Maintain } \\
\text { separation / } \\
\text { straight path* }\end{array}$ & 3.63 & $59 \%$ & 3.01 & $35 \%$ & 3.22 & $43 \%$ & 822 \\
\hline Mixing zone & 3.03 & $37 \%$ & 3.04 & $37 \%$ & 3.04 & $37 \%$ & 2207 \\
\hline Lateral Shift* & 3.14 & $40 \%$ & 2.80 & $32 \%$ & 2.97 & $36 \%$ & 1101 \\
\hline Total & 3.29 & $47 \%$ & 3.12 & $41 \%$ & 3.22 & $44 \%$ & 6338 \\
\hline n (ratings) & & 2756 & & 3307 & & 6338 & \\
\hline
\end{tabular}

3 *Significant difference in percentage comfortable between no interaction and interaction clips (Chi-Square, $\mathrm{p}<.05$ ).

$4 \quad{ }^{1}$ very or somewhat comfortable 
1 Table 4 Preference for design option and coded open-ended responses

\begin{tabular}{|c|c|c|c|c|c|c|c|c|c|}
\hline \multirow[b]{3}{*}{ Explanation of choice } & \multicolumn{2}{|c|}{$\begin{array}{l}\text { Mixing } \\
\text { Zone }\end{array}$} & \multicolumn{2}{|c|}{$\begin{array}{l}\text { Lateral } \\
\text { Shift }\end{array}$} & \multicolumn{2}{|c|}{$\begin{array}{l}\text { Protected } \\
\text { Intersection }\end{array}$} & \multicolumn{2}{|c|}{ Bend-in } & \multirow{2}{*}{$\begin{array}{c}\text { Grand } \\
\text { Total } \\
259\end{array}$} \\
\hline & 16 & $6 \%$ & 27 & $10 \%$ & 188 & $73 \%$ & 28 & $11 \%$ & \\
\hline & \multicolumn{9}{|c|}{$\begin{array}{l}\text { Of those selecting the design, number, and percent who mentioned } \\
\text { each factor }\end{array}$} \\
\hline $\begin{array}{l}\text { Mentioned either separation, not having to } \\
\text { merge, protection, curb or extra space }\end{array}$ & 1 & $6 \%$ & 2 & $7 \%$ & 111 & $59 \%$ & 13 & $46 \%$ & 127 \\
\hline Like the separation for bikes and vehicles & 1 & $6 \%$ & 2 & $7 \%$ & 52 & $28 \%$ & 5 & $18 \%$ & 60 \\
\hline Like not having to merge with vehicles & & & & & 2 & $1 \%$ & 1 & $4 \%$ & 3 \\
\hline Like the protection from vehicles & & & & & 44 & $23 \%$ & 5 & $18 \%$ & 49 \\
\hline $\begin{array}{r}\text { Specifically cited the curb or concrete } \\
\text { barrier }\end{array}$ & & & & & 48 & $26 \%$ & & & 48 \\
\hline Like having extra space & & & & & 15 & $8 \%$ & 4 & $14 \%$ & 19 \\
\hline The bike lane is clearly marked / delineated & 1 & $6 \%$ & 3 & $11 \%$ & 29 & $15 \%$ & 5 & $18 \%$ & 38 \\
\hline $\begin{array}{l}\text { Mentioned either visibility or making the } \\
\text { driver more alert }\end{array}$ & 2 & $13 \%$ & 4 & $15 \%$ & 35 & $19 \%$ & 6 & $21 \%$ & 47 \\
\hline $\begin{array}{r}\text { Like the visibility for either bicyclist or } \\
\text { driver }\end{array}$ & & & 4 & $15 \%$ & 28 & $15 \%$ & 3 & $11 \%$ & 35 \\
\hline Design makes drivers more alert & 2 & $13 \%$ & 2 & $7 \%$ & 7 & $4 \%$ & 3 & $11 \%$ & 14 \\
\hline Like the color/green in the design. & & & & & 12 & $6 \%$ & 3 & $11 \%$ & 15 \\
\hline $\begin{array}{l}\text { Mentioned either time to react or drivers } \\
\text { needing to slow }\end{array}$ & & & & & 21 & $11 \%$ & 1 & $4 \%$ & 22 \\
\hline Provide time and space to react & & & & & 14 & $7 \%$ & 1 & $4 \%$ & 15 \\
\hline Drivers must slow & & & & & 10 & $5 \%$ & & & 10 \\
\hline Less confusing design & 1 & $6 \%$ & 5 & $19 \%$ & 4 & $2 \%$ & 5 & $18 \%$ & 15 \\
\hline Like yield markings & 8 & $50 \%$ & & & & & & & 8 \\
\hline Like bike lane width & & & & & 6 & $3 \%$ & 1 & $4 \%$ & 7 \\
\hline Like that vehicles cross prior to turning & & & 5 & $19 \%$ & & & & & 5 \\
\hline More direction option & & & 2 & $7 \%$ & & & 2 & $7 \%$ & 4 \\
\hline Right of way is clear & & & & & 4 & $2 \%$ & & & 4 \\
\hline
\end{tabular}

2 Note multiple codings to the open-ended responses are possible; subtotal sections do not necessarily total. 
Table 5 K-Means Cluster Groups, Characteristics

\begin{tabular}{|c|c|c|c|}
\hline Group & $\begin{array}{l}\text { Indifferent } \\
\text { to Bicycling }\end{array}$ & $\begin{array}{c}\text { Bike } \\
\text { Inclined }\end{array}$ & $\begin{array}{c}\text { Interested but } \\
\text { Concerned }\end{array}$ \\
\hline \multicolumn{4}{|c|}{ Bike related attitudes and perceptions (basis of clusters) - Percentage indicating agreement } \\
\hline I would like to ride a bicycle more than I currently do & $72 \%$ & 93\% & 99\%b \\
\hline Traffic on streets keeps me from riding a bike (or riding more) & $54 \%$ a & $43 \%$ a & $98 \%$ \\
\hline Many places I need to go are within a reasonable biking distance & $40 \%$ a & $97 \%$ & $91 \%$ b \\
\hline I often see people riding bikes in my neighborhood & $62 \%$ a & $100 \% \mathrm{~b}$ & $87 \%_{c}$ \\
\hline I often see people like me riding bikes in my neighborhood & $32 \%$ a & $100 \% \mathrm{~b}$ & $51 \%{ }_{c}$ \\
\hline I prefer to get around by modes other than by riding a bicycle & $82 \%$ a & $41 \% \mathrm{~b}$ & $73 \%$ a \\
\hline Bike lanes make it harder to get around my neighborhood & $20 \%$ a & $3 \%$ & $14 \%$ a \\
\hline I usually have to transport things or people when I travel & $73 \%$ ab & $61 \%$ b & $78 \%$ a \\
\hline $\begin{array}{l}\text { I would like my city/town to invest in projects (such as bike } \\
\text { lanes) that make riding bikes safer and easier }\end{array}$ & $86 \%$ a & $99 \%$ b & $97 \%$ b \\
\hline \multicolumn{4}{|c|}{ Behavior and Demographics } \\
\hline Bike for transport in past month & $15 \%$ a & $60 \%$ & $26 \%$ a \\
\hline Most trips by car (past week) & $71 \%$ a & $38 \% \mathrm{~b}$ & $62 \%$ a \\
\hline Have transit pass & $27 \%$ a & $52 \%$ & $53 \%$ b \\
\hline Female & $52 \%$ a & $42 \%$ a & $70 \%$ b \\
\hline White & $57 \%$ a & $83 \%$ b & $65 \%$ a \\
\hline \multicolumn{4}{|c|}{ Zipcode characteristics } \\
\hline Zipcode - Mean population density* & $59,144_{a}$ & $72,728_{\mathrm{ab}}$ & $84,766_{b}$ \\
\hline Zipcode - Mean percent white population* & $73 \%$ a & $68 \%$ ab & $62 \%$ b \\
\hline $\mathrm{n}$ & 72 & 93 & 93 \\
\hline
\end{tabular}

$a, b, c$ : Each subscript letter denotes a subset whose column proportions do not differ significantly from each other

3 at the .05 level. (Chi-square with posthoc Z-test or ANOVA with Tukey post-hoc*) 
Monsere, McNeil, and Sanders

1 Table 6 Percentage comfortable by clip location, K-Means Cluster groups

\begin{tabular}{|c|c|c|c|c|c|c|c|c|c|}
\hline \multirow{2}{*}{$\begin{array}{l}\text { Intersectio } \\
\text { n Design }\end{array}$} & \multicolumn{2}{|c|}{$\begin{array}{c}\text { Indifferent to } \\
\text { Bicycling }\end{array}$} & \multicolumn{2}{|c|}{ Bike Inclined } & \multicolumn{2}{|c|}{$\begin{array}{c}\text { Interested but } \\
\text { Concerned }\end{array}$} & \multicolumn{2}{|r|}{ Total } & \multirow{2}{*}{$\begin{array}{c}\text { \# of } \\
\text { - Rati } \\
\text { ngs }\end{array}$} \\
\hline & $\begin{array}{l}\text { Mean } \\
\text { Rating }\end{array}$ & $\begin{array}{c}\text { Percentage } \\
\text { Comfortable }^{1}\end{array}$ & $\begin{array}{l}\text { Mean } \\
\text { Rating }\end{array}$ & $\begin{array}{c}\text { Percentage } \\
\text { Comfortable }^{1} \\
\end{array}$ & $\begin{array}{l}\text { Mean } \\
\text { Rating }\end{array}$ & $\begin{array}{c}\text { Percentage } \\
\text { Comfortable }^{1} \\
\end{array}$ & $\begin{array}{l}\text { Mean } \\
\text { Rating }\end{array}$ & $\begin{array}{c}\text { Percentage } \\
\text { Comfortable }^{1} \\
\end{array}$ & \\
\hline $\begin{array}{l}\text { Mixing } \\
\text { zone }\end{array}$ & 2.93 & $33 \%$ a & 3.34 & $48 \%$ b & 2.83 & $29 \%$ a & 3.04 & $37 \%$ & 2058 \\
\hline $\begin{array}{l}\text { Protected } \\
\text { Intersection }\end{array}$ & 3.67 & $62 \%$ a & 4.08 & $75 \%$ b & 3.67 & $64 \%$ a & 3.82 & $67 \%$ & 772 \\
\hline $\begin{array}{l}\text { Lateral } \\
\text { Shift }\end{array}$ & 2.86 & $32 \% a$ & 3.35 & $51 \%$ & 2.70 & $27 \%$ a & 2.98 & $37 \%$ & 1026 \\
\hline $\begin{array}{l}\text { Bend in } \\
\text { Maintain }\end{array}$ & 3.20 & $44 \%$ a & 3.60 & $57 \%$ & 3.12 & $40 \%$ a & 3.32 & $47 \%$ & 1030 \\
\hline $\begin{array}{l}\text { separation / } \\
\text { straight } \\
\text { path }\end{array}$ & 3.21 & $46 \%$ a & 3.51 & $53 \%$ a & 2.98 & $34 \%$ & 3.24 & $44 \%$ & 766 \\
\hline Signal & 3.65 & $61 \% a$ & 3.97 & $73 \% a$ & 3.65 & $65 \% a$ & 3.76 & $66 \%$ & 256 \\
\hline Total & 3.13 & $41 \%{ }_{a}$ & 3.53 & $55 \%$ & 3.02 & $37 \%_{c}$ & 3.24 & $45 \%$ & 5908 \\
\hline
\end{tabular}

Number of ratings total 1642 2137 2129 5908

2 a, b, c: Each subscript letter denotes a subset whose column proportions do not differ significantly from each other at 3 the .05 level. (Chi-square with posthoc Z-test)

$4 \quad{ }^{1}$ Somewhat or Very Comfortable 
Monsere, McNeil, and Sanders

1 Table 7 Willingness to Ride Kids, K-Means Cluster groups

\begin{tabular}{|c|c|c|c|c|}
\hline \multirow{2}{*}{$\begin{array}{l}\text { Intersection description and } \\
\text { location }\end{array}$} & \multicolumn{4}{|c|}{$\begin{array}{l}\text { Percent indicating that they would consider riding in the } \\
\text { location with a ten-year-old child }\end{array}$} \\
\hline & $\begin{array}{l}\text { Indifferent to } \\
\text { Bicycling }\end{array}$ & Bike Inclined & $\begin{array}{l}\text { Interested but } \\
\text { Concerned }\end{array}$ & Total \\
\hline $\begin{array}{l}\text { Protected intersection } \\
(200 \mathrm{~W} \text { at } 300 \mathrm{~S} \mathrm{NB})\end{array}$ & $58 \%$ a & $76 \%$ b & $68 \%$ ab & $68 \%$ \\
\hline $\begin{array}{l}\text { Lateral shift - post delineated } \\
\text { (Roosevelt at 50th SB) }\end{array}$ & $24 \%$ a & $45 \%$ b & $23 \%$ & $31 \%$ \\
\hline $\begin{array}{l}\text { Short mixing zone } \\
\text { (300S at } 200 \mathrm{E} \mathrm{EB})\end{array}$ & $17 \%$ a & $33 \%$ & $23 \%$ ab & $25 \%$ \\
\hline $\begin{array}{l}\text { Bend-in } \\
\text { (14th at Delaware EB) }\end{array}$ & $72 \%$ & $68 \%$ & $73 \%$ & $71 \%$ \\
\hline $\begin{array}{l}\text { Separated bike lane segment } \\
\text { (NE Multnomah) }\end{array}$ & $84 \%$ & $94 \%$ & $89 \%$ & $89 \%$ \\
\hline $\begin{array}{l}\text { Maintain Separation- straight path } \\
\text { (NE Multnomah at } 11 \text { th EB) }\end{array}$ & $50 \%$ & $54 \%$ & $52 \%$ & $52 \%$ \\
\hline
\end{tabular}

2 a, b, c: Each subscript letter denotes a subset whose column proportions do not differ significantly from each other at 3 the .05 level. (Chi-square with posthoc Z-test) 
Monsere, McNeil, and Sanders

1 Table 8 Independent Linear Regressions of Comfort on Exposure Distance Measures

\begin{tabular}{|c|c|c|c|c|}
\hline & $\begin{array}{l}\text { Indifferent to } \\
\text { Bicycling } \\
\end{array}$ & $\begin{array}{l}\text { Bike } \\
\text { Inclined }\end{array}$ & $\begin{array}{l}\text { Interested but } \\
\text { Concerned }\end{array}$ & Total \\
\hline \multicolumn{5}{|c|}{ Model Summaries } \\
\hline $\mathrm{R}^{*}$ & .288 & .266 & .303 & .274 \\
\hline R Square & 0.083 & 0.071 & 0.092 & .075 \\
\hline Std. Error of the Estimate & 1.075 & 1.054 & 1.133 & 1.116 \\
\hline \multicolumn{5}{|c|}{ Unstandardized Coefficients of Predictors } \\
\hline (Constant)* & 3.633 & 4.021 & 3.536 & 3.712 \\
\hline Mix / merge length* & -0.007 & -0.006 & -0.009 & -0.007 \\
\hline Crossing distance (ft.)* & -0.004 & -0.004 & -0.003 & -0.004 \\
\hline
\end{tabular}

2 *Significant $\mathrm{p}<0.01$ in each case 